BRITISH MEDICAL JOURNAL VOLUME 29218 JANUARY 1986

2 Szmuness $\mathrm{W}$, Stevens CE, Harley EJ, et al. Hepatitis B vaccine in medical staff of hemodialysis units: efficacy and subtype cross-protection. $N$ Englf $\mathrm{Med}$ 1982;307:1481-6.

3 McAleer WJ, Buynak EB, Maigetter RZ, Wampler DE, Miller WJ, Hilleman MR. Human hepatitis B vaccine from recombinant yeast. Nature 1984;307:178-80.

4 Hilleman MR, McAleer WJ, Buynak EB, McLean AA. Quality and safety of human hepatitis B vaccine. Dev Biol Stand 1983;54:3-12.

5 Stevens CE, Szmuness W, Goodman AI, Weseley SA, Fortino M. Hepatitis B vaccine: immune responses in haemodialysis patients. Lancet 1980;ii:1211-3.
rentions

6 Anonymous. Hepatitis B vaccine and haemodialysis [Editorial]. Lancet 1984;ii:962-3.

7 Feuerhake A, Muller R, Lauchart W, Pichlmayr R, Schmidt FW. HBV-vaccination in recipients of kidney allografts. Vaccine 1984;2:255-6.

8 Stevens CE, Alter HJ, Taylor PE, Zang EA, Harley EJ, Szmuness W. Hepatitis B vaccine in patients receiving hemodialysis: immunogenicity and efficacy. $N$ Engl f Med 1984;311: 496-501.

9 Galibert F, Mandart E, Fitoussi F, Tiollais P, Charnay P. Nucleotide sequence of the hepatitis B virus genome (subtype ayw) cloned in E coli. Nature 1979;281:646-50.

10 Pasak M, Gato F, Gilbert W, et al. Hepatitis B virus genes and their expression in E coli. Nature 1979;282:575-9.

11 Valenzuela P, Gray P, Quiroga M, Zaldivar J, Goodman HM, Rutter WE. Nucleotide sequence of the gene coding for the major protein of hepatitis B surface antigen. Nature 1979;280:815-9.

12 Valenzuela P, Medina A, Rutter WJ, Ammerer G, Hall BD. Synthesis and assembly of hepatitis B virus surface antigen particles in yeast. Nature 1982;298:347-50.

13 Harford N, Cabezon T, Crabeel M, Simden E, Rutgens A, DeWilde M. Expression of hepatitis B surface antigen in yeast. Dev Biol Stand 1983;54:125-30

14 Jilg W, Schmidt M, Zoulek G, Lorbeer B, Wilske B, Deinhardt F. Clinical evaluation of a recombinant hepatitis B vaccine. Lancet 1984;ii:1174-5.

15 Davidson $M$, Krugman S. Immunogenicity of recombinant yeast hepatitis B vaccine. Lancet 1985 ; : $108-9$

16 Papaevangelou G, Dandolos E, Roumeliotou-Karayannis A, Richardson SC. Immunogenicity of recombinant hepatitis B vaccine. Lancet 1985 ; ; $4555-6$.

17 Scolinck EM, McLean AA, West DJ, McAleer WJ, Miller WJ, Buynak EB. Clinical evaluation in healthy adults of a hepatitis B vaccine made by recombinant DNA. FAMA 1984;251:2812-5.

18 Dandolos E, Roumeliotou-Karavannis A, Richardson SC, Papaevangelou G. Safety and immunogenicity of a recombinant hepatitis B vaccine. $\mathcal{F} \mathrm{Med}$ Virol (in press).
19 Brown SE, Howard CR, Zuckerman AJ, Steward MW. Determination of the affinity of antibodies to hepatitis B surface antigen in human sera. 7 Immunol Methods 1984;72:41-8.

20 Brown SE, Howard CR, Zuckerman AJ, Steward MW. Affinity of antibody responses in man to hepatitis B vaccine determined with synthetic peptides. Lancet 1984:ii:184-7.

21 Lew AM. The effect of epitope density and antibody affinity on the ELISA as analysed by monoclonal antibodies. F Immunol Methods 1984;72:171-6.

22 Nimmo GR, Lew AM, Stanley CM, Steward MW. Influence of antibody affinity on the performance of different antibody assays. 7 Immunol Methods 1984;72:177-87.

23 Young P, Vaudin M, Dixon J, Zuckerman AJ. Preparation of hepatitis B polypeptide micelles from human carrier plasma. $\mathcal{F}$ Virol Methods 1982;4:177-85.

24 Bhatnager PK, Papas E, Blum HE, et al. Immune response to synthetic peptide analogues of hepatitis B. surface antigen specific for the a determinant. Proc Natl Acad Sci USA 1982;79:4400-4.

25 Prince AM, Ikram H, Hopp TP. Hepatitis B virus vaccine: identification of $\mathrm{HBsAg} / \mathrm{a}$ and $\mathrm{HBsAg} / \mathrm{d}$ but not $\mathrm{HBsAg} / \mathrm{y}$ subtype antigenic determinants on a synthetic immunogenic peptide. Proc Natl Acad Sci USA 1982;79:579-82.

26 Peterson DL. Isolation and characterization of the major protein and glycoprotein of hepatitis B surface antigen. F Biol Chem 1981;256:6975-83.

27 Shih JWK, Gerin JL. Proteins of hepatitis B surface antigen. Amino acid composition of the major polypeptides. 7 Virol 1977:21:1219-22.

28 Ionescu-Matiu I, Kennedy RC, Sparrow JT, et al. Epitopes associated with a synthetic hepatitis B surface antigen peptide. $\mathcal{F}$ Immunol 1983;130:1947-52.

29 Steward MW, Steensgaard J. Antibody affinity: thermodynamic aspects and biological significance. Boca Raton, Florida: CRC Press, 1983.

30 Alpers JH, Steward MW, Soothill JF. Differences in immune elimination in inbred mice. The role of low affinity antibody. Clin Exp Immunol 1972;12:121-32.

31 Blank SE, Leslie GA, Clem LW. Antibody affinity and valence in viral neutralization. $f$ I mmunol 1972;108:665-73.

32 Hughes-Jones NC. The estimation of the concentration and equilibrium constant of anti-D. Immunology 1967;12:565-71

\title{
Lactose absorption, milk consumption, and fasting blood glucose concentrations in women with idiopathic osteoporosis
}

\author{
G FINKENSTEDT， F SKRABAL， R W GASSER， H BRAUNSTEINER
}

\begin{abstract}
Lactose tolerance tests were performed in 33 women with osteoporosis and 33 control women matched for age. A questionnaire was used to elicit any history of milk intolerance and the subjects' daily intake of calcium derived from milk and dairy products. Eleven patients and four controls gave a history of milk intolerance $(p<0.01) ; 13$ patients had lactose malabsorption compared with four controls $(p<0.01)$. The daily intake of calcium derived from milk was significantly lower in patients $(125$ (SEM 20) mg v 252 (43) mg; $p<0.05$ ). Curves of blood glucose concentrations during the lactose tolerance test in subjects with lactose malabsorption were significantly flatter in patients than controls $(p<0.05)$. The fasting blood glucose concentration was higher $(5.44(0.17) \mathrm{mmol} / \mathrm{l}(98(3) \mathrm{mg} / 100 \mathrm{ml}))$ in the patients than the controls $(4.88(0.11) \mathrm{mmol} / 1(88(2) \mathrm{mg} / 100 \mathrm{ml}) ; \mathrm{p}<0.05)$, although body weight was significantly lower $(61 \cdot 6(2 \cdot 2) \mathrm{kg} v 66.3$ $(1.6) \mathrm{kg} ; \mathrm{p}<0.05)$.
\end{abstract}

Absorption of lactose is significantly impaired in women with "idiopathic" osteoporosis; this combined with low consumption

\footnotetext{
Department of Internal Medicine, University Hospital, University of Innsbruck, 6020 Innsbruck, Austria

G FINKENSTEDT, MD, senior registrar

F SKRABAL, MD, professor, chief of division of endocrinology and hypertension

R W GASSER, MD, senior registrar

$\mathrm{H}$ BRAUNSTEINER, MD, professor of internal medicine and head of department

Correspondence to: Dr Finkenstedt.
}

of milk and a subclinical disorder of glucose metabolism may be a major factor in the development of idiopathic osteoporosis in women.

\section{Introduction}

The contribution of malabsorption of lactose to the development of osteoporosis is not well documented. Birge et al and Newcomer et al found an increased incidence of lactose intolerance in patients with osteoporosis, ${ }^{12}$ while Alhava et al could not show any difference in bone mineral content between subjects with and without lactose intolerance. ${ }^{3}$ We determined the prevalence of lactose malabsorption and the amount of calcium consumed that was derived from milk and dairy products in 33 women with osteoporosis compared with 33 control women matched for age.

\section{Patients, methods, and results}

Thirty three women aged under 65 with "idiopathic" osteoporosis were compared with 33 women without osteoporosis (Singh index $>4$ ) of the same ethnic origin matched for age. We excluded patients with endocrine disorders, liver and renal disease, postgastrectomy states, malabsorption syndromes, rheumatoid arthritis, osteomalacia, and malignancy and patients receiving corticosteroids. Patients and controls were not taking drugs that influenced calcium or bone metabolism. Osteoporosis was confirmed by the presence of reduced bone mineral density in plain $x$ ray films and either a femoral trabecular index $<5^{4}$ or the presence of spontaneous fractures of vertebrae or long bones, or both.

Malabsorption of lactose was defined as a rise in glucose concentration of $<1.11 \mathrm{mmol} / \mathrm{l}(20 \mathrm{mg} / 100 \mathrm{ml})$ in capillary blood samples taken at 30 minute intervals after the ingestion of $50 \mathrm{~g}$ lactose dissolved in water. ${ }^{5}$ Patients were given a questionnaire asking about their mean daily or weekly ingestion of milk, yoghourt, cottage cheese, and other cheese and about tolerance to 
milk in childhood and later life. The daily calcium intake derived from milk and dairy products was calculated according to standard nutritional tables. ${ }^{6}$ Significance was assessed with the Mann-Whitney U test.

The table gives the clinical and biochemical data on the patients with osteoporosis and the controls. The prevalence of lactose malabsorption and of milk intolerance was significantly higher in the patients. The mean daily

Clinical and biochemical data on women with osteoporosis and controls matched for age

\begin{tabular}{|c|c|c|c|}
\hline & $\begin{array}{l}\text { Patients } \\
(\mathrm{n}=33)\end{array}$ & $\begin{array}{l}\text { Controls } \\
(n=33)\end{array}$ & $\mathrm{p}$ \\
\hline Mean age (range) (years) & $54(31-65)$ & $56(33-67)$ & \\
\hline No of patients with fractures & 14 & & \\
\hline Mean trabecular index (range) & $3(2-4)$ & $5(5-6)$ & \\
\hline Mean (SEM) body weight ( $\mathrm{kg}$ ) & $61 \cdot 6(2 \cdot 2)$ & $66 \cdot 3(1 \cdot 6)$ & $<0.05$ \\
\hline No with lactose malabsorption & 13 & 4 & $<0.01$ \\
\hline No with history of milk intolerance & 11 & 4 & $<0.01$ \\
\hline $\begin{array}{l}\text { Mean (SEM) total daily calcium intake from milk } \\
\text { and dairy products (mg) }\end{array}$ & $429(62)$ & $645(127)$ & NS \\
\hline $\begin{array}{l}\text { Mean (SEM) daily calcium intake from } \\
\text { milk (mg) }\end{array}$ & $125(20)$ & $252(43)$ & $<0.05$ \\
\hline Mean $(\mathrm{SEM})$ serum calcium $(\mathrm{mmol} / \mathrm{l})$ & $2.40(0.02)$ & $2 \cdot 38(0.01)$ & NS \\
\hline Mean (SEM) serum alkaline phosphatase (U/1) & $137(12)$ & $95(6)$ & $<0.01$ \\
\hline Mean (SEM) fasting blood glucose $(\mathrm{mmol} / \mathrm{l})$ & $5.44(0.17)$ & $4 \cdot 88(0 \cdot 11)$ & $<0.05$ \\
\hline $\begin{array}{l}\text { Mean (SEM) change in blood glucose during } \\
\text { lactose tolerance test }(\mathrm{mmol} / \mathrm{l}) \text { at: }\end{array}$ & & & \\
\hline $30 \mathrm{~min}$ & $1 \cdot 33(0 \cdot 28)$ & $2 \cdot 11(0 \cdot 28)$ & $<0.05$ \\
\hline $60 \mathrm{~min}$ & $1.00(0.28)$ & $2.05(0.33)$ & NS \\
\hline $90 \mathrm{~min}$ & $0.50(0.17)$ & $1.55(0.55)$ & $<0.05$ \\
\hline $120 \mathrm{~min}$ & $0.00(0 \cdot 17)$ & $0.94(0.33)$ & $<0.05$ \\
\hline
\end{tabular}

Conversion: SI to traditional units-Calcium: $1 \mathrm{mmol} / \mathrm{l} \approx 4 \mathrm{mg} / 100 \mathrm{ml}$. Glucose: $1 \mathrm{mmol} / 1 \approx 18 \mathrm{mg} / 100 \mathrm{ml}$.

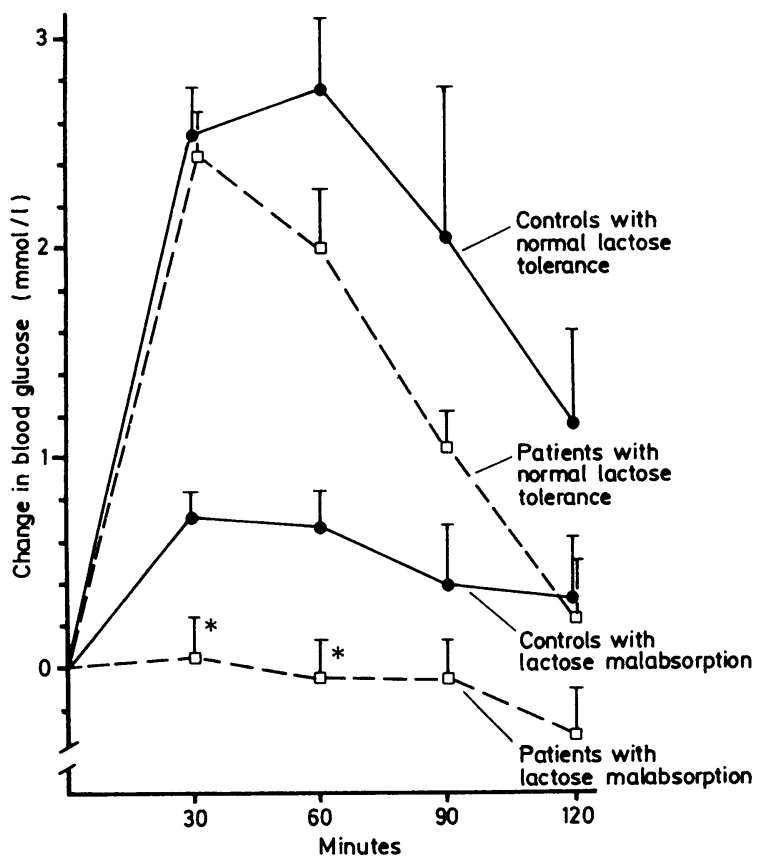

Increases in blood glucose concentrations during lactose tolerance test in patients with osteoporosis and controls with and without lactose malabsorption

${ }^{\star} \mathrm{p}<0.05$.

Conversion: SI to traditional units-Glucose: $1 \mathrm{mmol} / \mathrm{l} \approx 18 \mathrm{mg}$ $100 \mathrm{ml}$.

total calcium intake derived from milk and dairy products was marginally lower in the patients, whereas their daily calcium intake derived from milk was significantly lower. Unexpectedly, the fasting blood glucose concentrations were significantly higher in the patients, although their mean body weight was significantly lower. The increases in blood glucose concentration during the lactose tolerance test were significantly lower in the patients at 30 , 90 , and 120 minutes.

Increases in blood glucose concentrations during the lactose tolerance test were significantly lower at 30 and 60 minutes in the osteoporotic women with lactose malabsorption compared with the controls with lactose malabsorption. The same trend, though not significant, was observed in the patients and controls with normal lactose tolerance (figure).

\section{Discussion}

Although computed tomographic estimation of lumbar spine bone mineral content was not available at the start of the study, we believe that osteoporosis is confirmed by either a low trabecular index ${ }^{4}$ or the presence of spontaneous fractures, or both.

Our study confirms the finding of Newcomer et al of a high prevalence of lactose intolerance in postmenopausal women with osteoporosis compared with control women matched for age. ${ }^{2}$ Thus lactose malabsorption appears to be associated with the development of osteoporosis in women. The increased prevalence of lactose malabsorption in women with osteoporosis is reflected by the increased prevalence of milk intolerance in these patients.

Furthermore, we found that the daily calcium intake derived from milk was significantly lower in women with osteoporosis while total daily calcium consumption was only marginally lower. To our knowledge, this is the first study that has shown differences in milk (and milk calcium) consumption between women with osteoporosis and controls. Previous studies assessed total daily calcium intake, which was not different between the two groups. ${ }^{12}$ Though aware that estimates of dietary calcium intake are notoriously inaccurate, we believe that estimates of the calcium intake derived from milk are more reliable. Thus low milk consumption seems to be a further important factor in the development of osteoporosis in women.

Comparison of the blood glucose curves during the lactose tolerance tests between those with and without lactose malabsorption (figure) showed that the usual definition of lactose malabsorption as a rise in blood glucose concentration of less than $1.11 \mathrm{mmol} / \mathrm{l}(20 \mathrm{mg} / 100 \mathrm{ml})^{5}$ is arbitrary. Thus the increments in blood glucose concentration at 30 and 60 minutes in the group defined as having lactose malabsorption were significantly different between the patients with osteoporosis and the controls; in fact, blood glucose concentration virtually did not increase at all in this group of patients. Lactose tolerance curves were also flatter in patients with "normal" lactose absorption compared with corresponding controls (figure). Thus lactose absorption seems to be a gradual continuum from frank malabsorption to minor changes that may not cause clinical symptoms but may predispose to the development of osteoporosis over many years.

Interestingly, fasting blood glucose concentrations were significantly higher in the women with osteoporosis, although their body weight was lower. As diabetes mellitus is thought to predispose to osteoporosis ${ }^{7}$ this observation may point to a disturbance of glucose homoeostasis as an additional contributing factor in the development of osteoporosis. We are at present investigating glucose metabolism in these patients in detail, especially to exclude simple explanations such as a lesser degree of physical activity in patients with osteoporosis.

In conclusion, this study shows that lactose absorption is significantly impaired in women with idiopathic osteoporosis; low milk consumption and a subclinical disorder of glucose metabolism may be contributing factors in the development of osteoporosis.

We thank Miss M Hammer for help in evaluating the dietary histories and Dr D Zur Nedden for help in grading the radiographs.

\section{References}

1 Birge SJ, Keutmann HT, Cuatrecasas P, Whedon GD. Osteoporosis, intestinal lactase deficiency and low dietary calcium intake. $N$ Engl f Med 1967;276:445-8.

2 Newcomer AD, Hodgson FS, McGill DB, Thomas PJ. Lactase deficiency: prevalence in osteoporosis. Ann Intern Med 1978;89:218-20.

3 Alhava EM, Jussila J, Karjalainen P, Vuojolahti P. Lactose malabsorption and bone mineral content. Acta Med Scand 1977;201:281-3.

4 Singh M, Riggs BL, Beabout JW, Jowsey J. Femoral trabecular pattern index for evaluation of spinal osteoporosis. Ann Intern Med 1972;77:63-7.

5 Greenberger NJ, Isselbacher KJ. Disorders of absorption. In: Petersdorf RG, Adams RD Braunwald E, et al, eds. Harrison's principles of internal medicine. New York: McGraw-Hill, 1983:1735

6 Souci SW, Fachmann W, Kraut H. Food composition and nutritional tables. Stuttgart: Wissenschaftliche Verlagsgesellschaft, 1981.

7 Avioli LV. Osteoporosis: pathogenesis and therapy. In: Avioli AV, Krane SM, eds. Metabolic bone disease. New York: Academic Press, 1977:307.

(Accepted 24 October 1985) 